\title{
INTEGRATIVE APPROACH TO IMPLEMENTING LABOR PRODUCTIVITY PROJECTS IN LARGE INDUSTRIAL COMPANIES OPERATING ON THE TERRITORY OF THE PERM KRAI OF THE RUSSIAN FEDERATION
}

\author{
Viktor POPOV \\ Perm National Research Polytechnic University \\ Tatyana ALEXANDROVA, Aleksandr GERSHANOK \\ Perm State University
}

Elena BORSHCHEVSKAYA

Voronezh State University

\begin{abstract}
:
A purposeful growth in efficiency of large industrial companies largely depends on a balanced decision-making concerning the content, the cost, and the quality of corporate projects to increase business productivity. A traditional project management methodology does not allow improving all project's parameters simultaneously. This leads to difficulties in implementing the developed measures and in providing the planned productivity growth. To search balanced decisions in labor productivity projects it is suggested to use an integrated approach, focused on a range of efficient instruments from allied management fields. It is recommended to integrate project management methodology with some instruments of strategic and innovative management, production systems development concepts LEAN, QRM and Agile, human resource and project portfolio management. A model of an integrated approach to labor productivity projects, which was developed and tested, is reasonable to use in large companies to develop hi-tech products and conduct organizational changes.
\end{abstract}

Key words: project, labor productivity, searching for balanced decisions, integration, project parameters

\section{INTRODUCTION}

The problem of labor productivity growth is the cornerstone for the Russian economy. In Russia, this indicator is almost twice as low as in the leading world countries [1]. Unfavorable labor productivity dynamics is an extremely dangerous social and economic phenomenon that negatively affects the prospects for forming a highly competitive national economy and an improving the quality of life for Russian citizens. Therefore, increasing labor productivity in domestic companies is a priority that ensures the country's breakthrough scientific, technological and socio-economic development.

The level of labor productivity in the country is closely related to real corporate business productivity projects, which are developed and implemented at industrial enterprises. Such projects contribute to an increase in the resource use efficiency, modernization of production, they stimulate innovation and export activities of enterprises. Large industrial companies contribute the most to ensuring the labor productivity growth. They have a more developed technological base and a higher potential for productivity growth in comparison with representatives of small and medium-sized businesses.

To date, a fairly large number of publications have been presented, both on corporate project management [2, 3, $4]$ and on issues related to labor productivity management in enterprises $[5,6]$. However, the specifics of managing labor productivity projects have not yet been sufficiently studied, little research is being done at the junction of these scientific areas $[7,8]$, which in itself is an obstacle to achieving business productivity targets in individual industrial enterprises.

As a rule, labor productivity projects have a complex nature and require businesses to develop measures for the innovative transformation of their various areas. The increase in labor productivity, which must be achieved over a certain period, acts as the main target indicator of such projects. At the same time, the projects must be balanced 
concerning terms, cost, content and quality. The traditional project management methodology is based on waterfall design $[9,10]$ and is not able to fully ensure the improvement of all corporate projects parameters, and, therefore, cannot offer the most effective ways to achieve the target labor productivity growth indicators. Enterprises often face the problem of achieving labor productivity growth targets on time, while balanced decisions on various project's parameters are absent. This problem is especially relevant for enterprises that participate in state and regional labor productivity programs.

An integrative approach to labor productivity projects at industrial enterprises can partially solve this problem. Foreign and domestic authors [11, 12, 13, 14] consider the issues of studying the integrative approach in relation to various management processes. But they do not study the peculiarities of this approach in relation to the purposes of productivity growth projects. Conversely, when studying the problems of increasing labor productivity in enterprises [15], their solution is not considered from the standpoint of an integrative approach.

The aim of the study is to develop a model of an integrative approach to the implementation of labor productivity projects, which will contribute to the search for balanced solutions in the field of performance management at large industrial enterprises. To achieve this goal, the following three tasks had to be solved:

1) Choose a combination of management areas that is relevant for the practice of implementing labor productivity projects at large industrial enterprises;

2) Choose the management tools from the topical managerial areas that are most suitable for the implementation of labor productivity projects at large industrial enterprises;

3) Structure the integrative approach model in relation to the implementation of labor productivity projects at large industrial enterprises.

\section{METHODOLOGY}

The theoretical basis of the study is formed by the scientific works of Russian and foreign authors who study how the integrative approach methodology in management can be used to solve urgent problems related to the socioeconomic progress of society.

The information base of the study consists of statistical reports on the activities of Perm Krai's industrial enterprises, implementing corporate labor productivity projects in the framework of the "Labor productivity and employment support" [16] project, which is a priority national of the Russian Federation. The study also used the information provided by the autonomous non-profit organization of the Perm Krai "Regional Center of Competence in the Sphere of Labor Productivity".

To study the implementation features of the labor productivity projects, we took a sample of 7 large industrial enterprises participating in the national project "Labor productivity and employment support" for 2018-2019 (see Table 1). Among them were such well-known production companies as the Joint Stock Company NPO "Iskra",
Joint Stock Company "UEC-Perm Engines", Joint Stock Company "Nytvensky Metallurgical Plant", Joint Stock Company "Tool Plant - Perm Motors".

Table 1

Information about industrial enterprises participating in the national project of the Russian Federation "Labor productivity and employment support" in 2018-2019 on the territory of the Perm Krai

\begin{tabular}{|c|c|c|c|}
\hline $\begin{array}{l}\text { Enterprise } \\
\text { name }\end{array}$ & $\begin{array}{c}\text { Field } \\
\text { of activity }\end{array}$ & \begin{tabular}{|c|}
$\begin{array}{c}\text { Average } \\
\text { annual } \\
\text { number } \\
\text { of products, } \\
\text { people }\end{array}$ \\
\end{tabular} & \begin{tabular}{|c|} 
Average \\
annual reve- \\
nue from \\
product sales, \\
mllion rubles \\
\end{tabular} \\
\hline $\begin{array}{l}\text { Joint Stock Com- } \\
\text { pany "UEC-Perm } \\
\text { Engines" }\end{array}$ & $\begin{array}{l}\text { Production of } \\
\text { engines for civil } \\
\text { aviation, gas } \\
\text { turbines for gas } \\
\text { transportation }\end{array}$ & 7715 & 20252 \\
\hline $\begin{array}{l}\text { Joint Stock Com- } \\
\text { pany NPO "Iskra" }\end{array}$ & $\begin{array}{l}\text { Production of } \\
\text { rocket } \\
\text { and space tech- } \\
\text { nology, equip- } \\
\text { ment for oil re- } \\
\text { fineries }\end{array}$ & 2980 & 6250 \\
\hline $\begin{array}{l}\text { Limited Liability } \\
\text { Company } \\
\text { "Kungurskiy } \\
\text { Meat Processing } \\
\text { Plant" }\end{array}$ & $\begin{array}{l}\text { Production of } \\
\text { products from } \\
\text { meat of slaugh- } \\
\text { ter animals } \\
\text { and poultry } \\
\text { meat }\end{array}$ & 1406 & 4460 \\
\hline $\begin{array}{l}\text { Joint Stock Com- } \\
\text { pany «Sorbent» }\end{array}$ & $\begin{array}{l}\text { Production of } \\
\text { personal pro- } \\
\text { tective equip- } \\
\text { ment } \\
\text { for respiratory } \\
\text { organs, acti- } \\
\text { vated carbons, } \\
\text { water purifica- } \\
\text { tion systems } \\
\end{array}$ & 1150 & 3245 \\
\hline $\begin{array}{l}\text { Joint Stock Com- } \\
\text { pany "Nytvensky } \\
\text { Metallurgical } \\
\text { Plant" }\end{array}$ & $\begin{array}{l}\text { Manufacture of } \\
\text { rolled metal } \\
\text { products, cut- } \\
\text { lery } \\
\text { and kitchen } \\
\text { utensils }\end{array}$ & 1290 & 2296 \\
\hline $\begin{array}{l}\text { Joint Stock Com- } \\
\text { pany } \\
\text { «Medisorb» }\end{array}$ & $\begin{array}{l}\text { Manufacturing } \\
\text { of pharmaceu- } \\
\text { ticals }\end{array}$ & 781 & 2110 \\
\hline $\begin{array}{l}\text { Joint Stock Com- } \\
\text { pany "Tool Plant } \\
\text { - Perm Motors" }\end{array}$ & $\begin{array}{l}\text { Release of in- } \\
\text { strumental } \\
\text { products for } \\
\text { equipping } \\
\text { the production } \\
\text { of aircraft en- } \\
\text { gines, helicop- } \\
\text { ter gearboxes } \\
\text { and rocket en- } \\
\text { gines }\end{array}$ & 1187 & 1218 \\
\hline
\end{tabular}

Source: made by the authors based on data provided by the autonomous non-profit organization of the Perm Krai "Regional Center of Competence in the Sphere of Labor Productivity".

Enterprises from this sample belong to the serial type of production, show a fairly high innovative activity, have a 
corporate project management system, are focused on improving the existing production system, and have conducted advanced training of personnel in the field of strategic and project management. As of the end of 2019, in the Perm Krai the enterprises included in the sample accounted for $25 \%$ of the total number of enterprises participating in the national project of the Russian Federation "Labor productivity and employment support" and $45 \%$ of the total number of employees of enterprises involved in the implementation of this project.

The research applied the methodology of an integrative approach to management processes, focused on the convergence and interconnection of various areas of scientific knowledge. The basis for the formation of scientific research results consists in the core type of integration of industrial enterprises' management areas, which is aimed at a more efficient implementation of the labor productivity growth target indicators. In addition, the main provisions of the article were developed and substantiated using the methodology of critical thinking, the methodology of systemic and comparative analysis, the method of analyzing and synthesizing information, and the statistical method.

\section{RESEARCH RESULTS}

The enterprises, selected for the study, implement a systematic project approach to the process of developing new products and putting them into serial production [17, 18]. It is well adapted to the practice of Russian economic conditions, and, if used correctly, allows you to save resources and time by $20-30 \%$ in comparison with traditional methods of managing the processes of creating and mastering new products. At the same time, initially, its capabilities were limited by the use of a cascade (sequential) model of corporate project management $[9,10]$, which is characterized by a strict relationship between the basic project parameters: content, quality, cost and timing. Therefore, it is impossible to achieve significant improvement in one parameter of the project without compromising the other. If you strive to reduce the time for the project product manufacturing while maintaining its high quality, this will lead to the need to increase the project budget. If we focus on reducing the cost of project's work, then the achievement of such a goal will most likely lead to a decrease in quality requirements. It is impossible to overcome this limitation on the simultaneous improvement of all parameters of corporate projects that are developed and implemented at enterprises participating in the national labor productivity project only with the tools of traditional project management. To do this, it is necessary to use methods and tools from areas allied to project management of industrial enterprises, whose activities are related to the implementation of the national labor productivity project.

If we search for balanced solutions on various parameters of corporate projects at a large company, focused on ensuring the target indicator of growth in labor productivity, it is proposed to integrate the methodology of project management and related areas of management (Fig. 1).

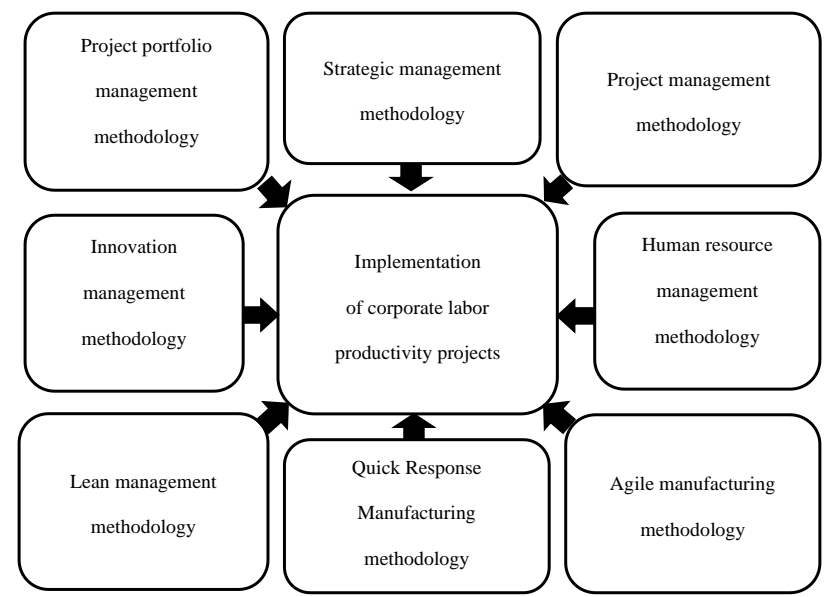

Fig. 1 Integration of approaches to implementation of corporate labor productivity projects at large industrial enterprises

These areas are necessary for highly efficient implementation of the developed projects, as management practice evidences. They include:

- Project portfolio management;

- Strategic management;

- Human resource management;

- Innovation management;

- Lean management (LEAN);

- Quick Response Manufacturing (QRM);

- Agile manufacturing (Agile).

\section{Project portfolio management}

As a rule, large companies develop more than one project to achieve the planned increase in labor productivity, which makes it necessary to create not only a project management subsystem, but also a project portfolio management system. The parameters of all implemented corporate projects can be simultaneously adjusted by mastering the tools for managing a portfolio of projects. This helps to timely achieve the global business goal - to fulfill the target parameters of the national project for the labor productivity growth. Project portfolio management allows you to apply a more flexible approach to providing resources for individual projects throughout the enterprise, to identify potential risks of implementing a national labor productivity project at the enterprise and to develop measures to compensate them in advance.

The most suitable tools of the project portfolio management methodology, which can be used by large companies focused on the business productivity growth, include:

- Projects should be prioritized and selected according to their impact on the achievement of the planned labor productivity growth;

- It should be taken into account how the projects influence each other in achieving the target for increasing labor productivity;

- The work on projects should be organized in order depending on the availability of resources;

- Companies should balance strategic and tactical projects for the labor productivity growth. 


\section{Strategic management}

The national project "Labor productivity and employment support" sets the minimum target indicator for productivity growth at the level of $5 \%$ per year. If an enterprise does not participate in this national project, it can independently plan an annual increase in labor productivity. Competent strategic management is particularly important, because it can increase the likelihood of achieving the planned increase. Labor productivity cannot be managed efficiently based on previous experience due to constantly emerging new technologies, unpredictable changes in the market situation, the unexpected appearance of new competitors. Strategic management should ensure the coordination of the efforts of company's employees to achieve the target increase in labor productivity.

The following strategic management tools can be used to increase the effectiveness of labor productivity measures at the enterprise:

- Development of a strategy for the labor productivity growth;

- Analysis of the strategic gap between the current and the desired level of the enterprise's productivity;

- Drawing up a tree of goals;

- Formation of the enterprise's key competencies in the labor productivity field.

\section{Human resource management}

The qualifications and competence of personnel play a crucial role in the successful implementation of labor productivity projects at individual enterprises. Since labor productivity projects are strategic in nature, individual participating enterprises show a tendency to replace the concept of "personnel management" with the concept of "human resource management" [5], which recognizes the need for investment in the formation, use and development of labor resources based on their economic feasibility in future activities of the enterprise. As a result, the work with personnel is carried out differently, in particular, attention is paid to such aspects of personnel management as identifying the hidden capabilities of an employee, the comprehensive development of their personality, the use of creative potential and the development of the competence. All this should take into account the strategic priorities of the enterprise.

- The purposes of labor productivity projects can be achieved with some tools of the "human resource management" concept. The most appropriate ones, in terms of training high-performance personnel, include:

- Proactive training of employees in new ways to increase labor productivity;

- Combining the interests of the enterprise and the employee in the area of personnel's labor productivity growth;

- Large-scale training of all personnel categories, the use of learning-by-doing technologies.

\section{Innovation management}

Innovation management is a necessary type of management activity of an enterprise that implements labor productivity projects. It is the innovation management that makes it possible to develop non-standard, creative solutions providing not only unique characteristics of a new product, but also reducing the time and cost of its development. Innovation management issues were first systematized in the British standard BS 7000-1: 2008 [19]. The domestic practice of innovation reflects them in the standards $[17,18]$. These standards regulate the organization of innovation management at Russian enterprises and describe the tools for finding innovative solutions. The corporate projects for the labor productivity growth can effectively use the following innovative management tools:

- Reengineering of business processes;

- Group search for innovative ideas;

- Improving the culture of innovation;

- Overcoming resistance to innovation.

\section{Lean management}

The production system of the Japanese automobile manufacturer TOYOTA (TPS), known in the USA as LEAN, and in Russia as Lean Production, has gained wide recognition and practical application in enterprises of various industries and services. The concept is attractive because the increase in labor productivity is ensured not through large investments in innovations, but through the internal resources of the enterprise using the initiative and intellectual potential of the personnel $[20,21]$. The most widespread LEAN tools and methods in Russia include 5C system; eliminating 8 types of losses; value stream map; KAIZEN; visualization; quick equipment changeover.

If we search for balanced solutions when achieving the goals of labor productivity projects, KAIZEN is the most suitable tool (approach to organizing the activities of an enterprise) for practical application of the LEAN concept. KAIZEN is a system of interrelated actions that improve the quality of the enterprise management system. In the context of corporate labor productivity projects, KAIZEN is focused on the continuous improvement of technological and managerial processes, product quality, organizational culture, leadership and other important aspects of the company's industrial activity. The KAIZEN system presupposes that each member of the project team is involved in the improvement process. It is based on such fundamental elements as teamwork; self-discipline and high morale of each member of the project team; priority of the project quality parameter; freedom to develop proposals for improving the project in order to find balanced solutions [21]. This organization of work means that a large number of minor improvements are introduced into individual structural elements of the project, which significantly improves the quality of the project as a whole.

\section{Quick Response Manufacturing}

The QRM concept is relatively recent and has the following advantages [22, 23]: 
- It covers the entire enterprise;

- It orientates the existing tools for improving production processes on saving time;

- It has a specific approach to the batch production planning process;

- It rejects the traditional organizational structure and forms multifunctional units;

- It does not focus on reducing the costs of individual operations, but on reducing the lead time for the entire order.

The QRM concept is based on several provisions that make it significantly different from the LEAN one. For example, to make production constantly ready to receive orders, the utilization of production facilities should not exceed $80 \%$. A flat organizational structure of management is introduced to reduce the unnecessary influence of the bureaucracy. It takes the form of production cells with a high level of self-government. The methodology for calculating the cost of production is being revised in terms of considering overhead costs as recurring, not as fixed ones [22]. Two tools of QRM concept can be included into the integrative model of finding balanced management decisions while implementing labor productivity projects: the creation of a production capacity reserve and the formation of a flat management structure based on project teams and multifunctional work cells.

\section{Agile manufacturing}

The concept of "agile manufacturing" is currently being developed. Some features have been formulated that distinguish enterprises using the Agile concept. They include the availability of flexible strategic plans of the company; the presence of a limited number of key highly qualified personnel; readiness to work in conditions with a high level of uncertainty [24]. The Agile methodology does not divide the entire project into sequential phases, but it divides it into small sub-projects, which form the final product. The Agile approach contains a set of ideas and principles for how to implement projects [25]. Agile's main strengths are its flexibility and adaptability. An enterprise where the Agile methodology is implemented is able to rebuild production resources in the shortest possible time and with minimal costs in order to take full advantage of unexpected opportunities. The Agile approach to the company's project management has several main values. The first one tells that it is better to give priority to people and interactions than processes and tools, when working on a project. The second value postulates that the result of the project is more important than the set of documentation. According to the third one, it is fundamentally important to build long-term cooperation with the customer. The fourth value considers that the project plan should be as flexible as possible [26].

Scrum is the most popular ready-made practice for Agile transformation of enterprise activities [27]. Scrum is characterized by flexibility and customer focus, since this approach presupposes that the client participates actively in the development of the project product. Scrum places very high demands on the project team. The project team should be small (5-9 people) and crossfunctional. Each member of the Scrum team must have several competencies required to design and implement a project. This requirement is introduced so that team members complement and replace each other, if necessary. Agile principles and Scrum methodology can be used to find balanced solutions for corporate labor productivity projects.

Figure 2 shows a conceptual model of an integrative approach to the implementation of corporate labor productivity projects, including the areas and management tools described above (Fig. 2).

\begin{tabular}{|l|c|l|l|}
\hline \multicolumn{2}{|c|}{ Integration goal: Searching for balanced solutions in the process of managing corporate } \\
projects aimed at ensuring the labor
\end{tabular}

Fig. 2 The model of an integrative approach to implementing corporate labor productivity projects in large industrial companies

It consists from several blocks. The initial block "The integration goal" formulates the goal of integrating the efforts of those participants of enterprises' activities who implement labor productivity projects. The central block "Integration areas" reflects the areas and management tools that are advisable to integrate in the implementation process of labor productivity projects at industrial enterprises. The "Integration Result" model block shows the result formed at the enterprise as a consequence of using an integrative approach to the implementation of corporate projects aimed at achieving target labor productivity indicators.

The model also contains blocks of input and output parameters that are used for quantitative calculations. Inputs are data that is communicated prior to the start of 
the integration process and is used to define the output parameters. Output parameters are performance indicators that quantitatively describe the goals of projects to increase labor productivity and characterize the ability of a given enterprise to implement these projects.

It should be noted that the selected input and output parameters are not absolutely complete, there are much more of them. The model (see Fig. 2) includes the most significant from the standpoint of large industrial enterprises and are more often used within the framework of the national project of the Russian Federation "Labor productivity and employment support".

The model proposed by the authors reflects the specific features of searching for balanced solutions as part of the implementation of corporate labor productivity projects at industrial enterprises. Integration of methodology and tools from various areas of management allows finding balanced solutions for the main parameters of the project: time, terms, content, cost and quality.

The model is recommended for use at large industrial enterprises implementing complex high-tech innovative projects to ensure the labor productivity growth. The main research results can also be used in research and expert organizations to develop programs and projects for the modernization of the country's industrial complex.

\section{DISCUSSION OF RESULTS AND DIRECTIONS FOR FURTHER RESEARCH}

These areas are necessary for highly efficient implementation of the developed projects, as management practice evidences. They include: in 2019, the authors developed the integrative approach to the implementation of corporate labor productivity projects, which was tested at 7 selected large industrial enterprises of the Perm Krai participating in the Russian national project "Labor productivity and employment support".

These companies integrated the efforts in several areas of management, which allowed them to speed up the process of project implementation, increase their practical effectiveness and ensure a higher increase in labor productivity. At the end of 2019, the selected enterprises of the Perm Krai showed the annual growth in labor productivity of $21-28 \%$, which is several times higher than the minimum indicator of $5 \%$ for participants in the national labor productivity project (see Table 1 ). Three out of seven enterprises were included in the TOP-100 industry leaders in Russia in terms of labor productivity growth in a sample of more than 5,000 enterprises. In addition, the accelerated growth of labor productivity formed the basis for all other improvements in the business functioning, which led to an increase in efficiency indicators in other areas of activity

Table 2 presents indicators characterizing the performance of large industrial enterprises from the sample in 2018 and 2019.
Table 2

Development dynamics of large industrial enterprises of the Perm Krai participating in the national project "Labor productivity and employment support", which introduced an integrative approach to the management of corporate labor productivity projects in 2019

\begin{tabular}{|l|c|c|}
\hline \multicolumn{1}{|c|}{ Indicator } & Year $\mathbf{2 0 1 8}$ & Year $\mathbf{2 0 1 9}$ \\
\hline Increase in labor productivity & $2-5 \%$ & $21-28 \%$ \\
\hline Increase in stock turnover & $5-10 \%$ & $16-24 \%$ \\
\hline Growth in new product output & $0 \%$ & $7-10 \%$ \\
\hline Decrease in unfinished goods & $5-15 \%$ & $35-40 \%$ \\
\hline Improving product profitability & $3-9 \%$ & $17-22 \%$ \\
\hline $\begin{array}{l}\text { Conclusion of new export con- } \\
\text { tracts }\end{array}$ & 0 contracts & 8 contracts \\
\hline
\end{tabular}

Source: made by the authors based on data provided by the autonomous non-profit organization of the Perm Krai "Regional Center of Competence in the Sphere of Labor Productivity".

In 2019, these indicators were calculated as the output parameters of the model of an integrative approach to the implementation of corporate projects to increase labor productivity (Fig. 2). In 2018, the same indicators were calculated without taking into account the implementation of this model. As can be seen from Table 2, the introduction in 2019 of an integrative approach to the implementation of corporate projects to increase labor productivity led to a positive trend in the performance indicators of the enterprise in comparison with 2018, when the integration of project efforts was not carried out.

However, industrial enterprises showed certain difficulties along with the positive effect of using an integrative approach to managing labor productivity projects. The reason for these problems lies in the fact that the process of managing corporate projects has become more complex and multidimensional. The company's staff members were required to have a higher level of qualifications in the field of project management, a deeper knowledge of how business processes function and interact. To solve these problems, selected enterprises organized corporate training.

An integrative approach to the management of labor productivity projects caused another problem. The development and implementation of balanced solutions showed the low level of activities' coordination between structural divisions, departments and services of the company's management apparatus. This problem can be solved by using modern digital technologies more actively to exchange information rapidly and to coordinate business issues promptly.

The study has some limitations. It considers only two areas of integrating enterprise's efforts in the implementation of labor productivity projects: by areas and management tools, while large industrial business has other opportunities for finding balanced solutions.

The use of an integrative approach to the implementation of labor productivity projects at large industrial enterprises has some promising areas for further research. 
They include:

- Integrating business processes involved in achieving the target parameters of corporate labor productivity projects;

- Developing a mechanism for adapting managers and employees of the companies' management apparatus to the implementation of various integration procedures aimed at achieving the goals of labor productivity projects more efficiently;

- Integrating the competencies the industrial enterprises' personnel in the field of labor productivity management.

Ultimately, the development of integration processes in various areas of industrial enterprise management will contribute both to an increase in the efficiency of the production system as a whole, and to an increase in the speed, accuracy and quality of managerial decisions made while implementing labor productivity projects.

\section{CONCLUSION}

- The research results include:

- The study developed a model of an integrative approach to the implementation of labor productivity projects at large industrial enterprises, which can serve as a basis for making balanced decisions on various parameters of corporate projects within the framework of the national project of the Russian Federation "Labor productivity and employment support" in the Perm Krai;

- The developed model has passed practical testing at large business enterprises operating in the Perm Territory of the Russian Federation. The impact of an integrative approach to project management of labor productivity growth on the indicators of a sample group of large industrial enterprises of the Perm Territory participating in the implementation of the national project "Labor productivity and employment support" in 2018 and 2019 is analyzed. Based on the results of the analysis, positive effects were revealed, indicating the favorable impact of the proposed management approach on the achievement of target indicators of corporate projects for the growth of labor productivity;

- The research concluded that the use of an integrative approach to the management of corporate labor productivity projects not only increases the efficiency of industrial enterprises, but also causes new problems associated with the practical application of new knowledge, competencies and skills in various business processes. Enterprise managers are required to timely identify such problems and develop measures to eliminate them.

The results of the study contribute to the development of the project management theory, specifying how the integrative approach can be applied for the labor productivity growth in the field of large industrial business. The practical application of the research results will make it possible to more reasonably and effectively implement projects to increase labor productivity both at individual industrial enterprises and within the framework of the large-scale national project of the Russian Federation "Labor productivity and employment support".

\section{ACKNOWLEDGEMENTS}

The The authors express their deep gratitude to Olga Sergeevna Krasavina, HR-Director of PJSC "UEC-Perm Engines" and Sergei Igorevich Sobolev, Deputy General Director for Information Technology, Joint Stock Company NPO "Iskra", whose practical advice and valuable comments were taken into account while working on this article.

\section{REFERENCES}

[1] O.B. Ivanov, E.M. Buchwald. (2019). "National Productivity Project: The key to the "economic spurt" for Russia". ETAP: Economic theory. Analysis. Practice, no. 3, pp. 28-41. Available: https://doi.org/10.24411/2071-6435-2019-10078

[2] A.E. Keegan, R. Turner. (2002). "The Management of Innovation in Project-Based Firms". Long Range Planning, vol. 35, no. 4, pp. 367-388. Available: http://dx.doi.org/10.1016/S0024-6301(02)00069-9

[3] R.K. Wysocki. (2019). „Effective Project Management: Traditional, Agile, Extreme, Hybrid". $8^{\text {th }}$ Edition. New York, Wiley.

[4] Ja. Vrchota, P. Rehor. (2019). „Project management and innovation in the manufacturing industry in Czech Republic". Procedia Computer Science, no. 164, pp. 457-462. Available: https://doi.org/10.1016/j.procs.2019.12.206

[5] A.S. Gamage. (2015). "The Role of HRM in Improving Labour Productivity: An Analysis of Manufacturing SMEs in Japan". Sri Lankan Journal of Human Resource Management, vol. 5, no. 1, pp. 44-59. Available: file:///F:/\%D0\%B7\%D0\%B0\%D0\%B3\%D1\%80\%D1\%83\%D 0\%B7\%D0\%BA\%D0\%B8/5627-20051-1-SM\%20(1).pdf

[6] P. Preenen, R. Vergeer, K. Kraan (2017). „Labour productivity and innovation performance: The importance of internal labour flexibility practices". Economic and Industrial Democracy, vol. 38, no. 2, pp. 271-293. Available: https://doi.org/10.1177/0143831X15572836

[7] M.M. Shagufta, S.S. Orr. (2021). „Agile practices and performance: Examining the role of psychological empowerment". International Journal of Project Management, vol. 39, no. 1 , pp. 10-20. Available: https://doi.org/10.1016/j.ijproman.2020.09.002

[8] Yu.V. Dolzhenkova, M.V. Field, E.V. Kamneva (2019). „The state and prospects for employee productivity growth as part of the national project "Productivity and Employment Support". Economy. Taxes. Right, 12(6): vol. 12, no. 6, pp. 6-16. Available: https://doi.org/10.26794/1999-849X2019-12-6-6-16

[9] R. Picciotto. (2020). „Towards a 'New Project Management' movement? An international development perspective". International Journal of Project Management, vol. 38, no. 8, pp. 474-485. Available: https://doi.org/10.1016/j.ijproman.2019.08.002

[10] „A Guide to the Project Management Body of Knowledge, (PMBOK Guides)". (2004). Third Edition. Newtown: Project Management Institute.

[11] C.G. Bocea. (2011). „Project based organization - an integrated approach". Management \& Marketing, vol. 9, no. 2, pp. 265-273. Available: http://www.mnmk.ro/documents/2011-2/9_Bocean\%20FFF.pdf

[12] D.F. Cioffi. (2020). „Managing Project Integration”. $1^{\text {st }}$ edition. Auckland: Berrett-Koehler Publishers. 
[13] S.M. Lo, H.P. Shen, J.C. Chen. (2017). „An integrated approach to project management using the Kano model and QFD: an empirical case study". Total Quality Management \& Business Excellence, vol. 28, no. 13-14, pp. 1584-1608. Available: https://doi.org/10.1080/14783363.2016.1151780

[14] M.Y. Parfenova. (2013). „Methodological aspects of an integrative approach to management based on the convergence of classical approaches". Humanitarian, socio-economic and social sciences: scientific electronic journal, no. 4, pp. 2-10. Available: https://www.online-science.ru/m/products/economi_sciense/gid607/pg0/

[15] V. Goel, R. Agrawal, V. Sharma. (2017). „Factors affecting labour productivity: an integrative synthesis and productivity modelling". Global Business and Economics Review, vol. 19, no. 3, pp. 299-322. Available: http://dx.doi.org/10.1504/GBER.2017.083964

[16] „Passport of the national project "Labor productivity and employment provision". (2018). Available: http://government.ru/info/35567/

[17] „Design management systems. Innovation Management Guide. Russia Standard 55347-2012". (2014). Moscow: StandardInform.

[18] „Innovative management. Innovation Management Guide. Russia Standard 57313-2016". (2017). Moscow: Standardinform.

[19] „BS 7000-1:2008 Design management systems. Guide to managing innovation". (2008). London: British Standards Institution.
[20] E. Lander, J.K. Liker. (2007). „The Toyota Production System and Art: Making Highly Customized and Creative Products the Toyota Way". International Journal of Production Research, vol. 45, no. 16, pp. 3681-3698. Available: https://doi:10.1080/00207540701223519

[21] L. Wilson. (2015). „How To Implement Lean Manufacturing". Second Edition, $2^{\text {nd }}$ Edition. Philadelphia, McGrawHill Education.

[22] R. Suri. (2016). „It's About Time: The Competitive Advantage of Quick Response Manufacturing". Portland: Productivity Press.

[23] M.G. Filho, A.C. Marchesini, R.N. Vandaele, D.C. Ganga. (2017). „The extent of knowledge of Quick Response Manufacturing principles: an exploratory transnational study". International Journal of Production Research, vol. 55, no. 17, pp. 4891-4911. Available: https://doi.org/10.1080/00207543.2016.1268729

[24] C.R. Borba, L.C. Trabasso, M.V. Pessôa. (2019). „Agile Management in Product Development". Research-Technology Management, vol. 62, no. 5, pp. 63-67. Available: https://doi.org/10.1080/08956308.2019.1638488

[25] „A Guide to the Project Management Body of Knowledge (PMBOK(R)". (2017). Sixth Edition. Newtown: Project Management Institute.

[26] M. Cohn. (2015). „Agile Estimating and Planning”. $1^{\text {st }}$ Edition. Harlow, Pearson.

[27] K. Rubin. (2012). „Essential Scrum: A Practical Guide to the Most Popular Agile Process", $1^{\text {st }}$ Edition. Reading, AddisonWesley Professional.

\section{Viktor Popov}

ORCID ID: 0000-0002-8490-3105

Perm National Research Polytechnic University

Komsomolskiy prospect, 29, Perm, Russia

e-mail:pku06@mail.ru

\section{Tatyana Alexandrova}

ORCID ID: 0000-0002-0049-1650

Perm State University

Bukireva street, 15, Perm, Russia

e-mail: atvpsu@yandex.ru

\section{Aleksandr Gershanok \\ ORCID ID: 0000-0002-0172-6845 \\ Perm State University \\ Bukireva Street, 15, Perm, Russia \\ e-mail: agershanok@yandex.ru}

\section{Elena Borshchevskaya}

ORCID ID: 0000-0002-3375-8235

Voronezh State University

Universitetskaya Square, 1, Voronezh, Russia

e-mail: ebogah0578@yandex.ru 